\title{
Productivity and nodulation of promising lineages of the Carioca bean group inoculated with Rhizobium tropici or supplemented with nitrogen fertilizer ${ }^{1}$
}

\section{Produtividade e nodulação de linhagens promissoras de feijoeiro do grupo Carioca inoculadas com Rhizobium tropici ou supridas com adubo nitrogenado ${ }^{1}$}

\author{
Auro Akio Otsubo $2^{*}$; Osmar Rodrigues Brito ${ }^{3}$; Fábio Martins Mercante ${ }^{2}$
}

\begin{abstract}
The aim of this study was to evaluate the nodulation and productivity of lineages of the bean group Carioca inoculated with Rhizobium tropici or fertilized with nitrogen. The experiments were conducted in Dourados, MS, Brazil, in 2008 (experiment 1) and 2009 (experiment 2). The experiment was performed in randomized blocks in triplicate in a $2 \times 14$ factorial, in which the factors were two different forms of nitrogen supply (mineral $\mathrm{N}$ or rhizobia inoculation). We used 14 different bean lineages. The seeds were inoculated with a mixture of the $R$. tropici strains CIAT 899 (SEMIA 4077) and PRF 81 (SEMIA 4080). For the majority of the new strains tested, the grain productivity of the common bean were similar for plants inoculated with $R$. tropici and those fertilized with $80 \mathrm{~kg} \mathrm{~N}^{-1}$. The different nodulation and phytotechnical parameter behaviors of some strains demonstrated that the source of $\mathrm{N}$ (inoculation of Rhizobium or nitrogen fertilization) in studies on breeding for the selection of bean cultivars can directly affect their yield potential.
\end{abstract}

Key words: Phaseolus vulgaris, biological fixation of nitrogen, genotypes

\section{Resumo}

O trabalho teve por objetivo avaliar a nodulação e produtividade de linhagens de feijoeiro do grupo Carioca quando submetidas à inoculação com Rhizobium tropici ou à adubação nitrogenada. Os experimentos foram conduzidos em Dourados, MS, nos anos de 2008 (experimento 1) e 2009 (experimento 2). O delineamento experimental utilizado foi o de blocos ao acaso, com três repetições, em um esquema fatorial 2x14, em que os fatores foram as duas formas de fornecimento de nitrogênio ( $\mathrm{N}$-mineral e inoculação com rizóbio) e 14 diferentes linhagens de feijoeiro, em cada experimento. As sementes foram inoculadas com uma mistura das estirpes CIAT 899 (SEMIA 4077) e PRF 81 (SEMIA 4080) de $R$. tropici. Para a maioria das linhagens avaliadas, as produtividades de grãos do feijoeiro foram similares entre as plantas inoculadas com $R$. tropici e aquelas adubadas com $80 \mathrm{~kg} \mathrm{ha}^{-1} \mathrm{de} \mathrm{N}$. O comportamento diferenciado de algumas linhagens quanto à nodulação e parâmetros fitotécnicos demonstra que a fonte

\footnotetext{
${ }^{1}$ Parte da tese apresentada à Universidade Estadual de Londrina, UEL, Londrina, PR, para obtenção do título de doutor do primeiro autor.

${ }^{2}$ Pesquisadores Drs. da Embrapa Agropecuária Oeste, Dourados, MS, Brasil. E-mail: auro.otsubo@embrapa.br; fabio.mercante@ embrapa.br

${ }^{3}$ Prof. Dr. do Dept ${ }^{\circ}$ de Agronomia, UEL, Londrina, PR, Brasil. E-mail: osmar@uel.br

* Author for correspondence
} 
de fornecimento de $\mathrm{N}$ (inoculação de rizóbio ou adubação nitrogenada) nos estudos de melhoramento genético para seleção de cultivares de feijoeiro pode influenciar diretamente no seu potencial produtivo.

Palavras-chave: Phaseolus vulgaris, fixação biológica de nitrogênio, genótipos

\section{Introduction}

Brazil is the largest global producer and consumer of the common bean (Phaseolus vulgaris L.), and $60 \%$ of its production is from areas or properties where family agriculture is practiced (COMISSÃO TÉCNICA SUL-BRASILEIRA DE FEIJÃO, 2010) [Southern Brazil Technical Commission for Beans]. The average productivity of beans in Brazil remains low because of improper handling of nutrients, particularly nitrogen, which is the nutrient required in the largest quantities by the bean plant (FANCELLI; DOURADO NETO, 2007).

Various studies report the positive effect nitrogen fertilization has on bean plant productivity when it is applied as a covering, used in direct planting, or when used in the water harvest (LEMOS et al., 2003; BINOTTI et al., 2010). However, the uncontrolled use or inappropriate handling of nitrogen fertilizers can result in pollution of surface or subterranean waters in addition to increasing production costs. During the manufacture of nitrogen fertilizers there is significant energy consumption of fossil fuels, and after it is applied to the soil, large losses can occur through leaching, volatilization, or denitrification; thus, decreasing the agronomic efficiency of these fertilizers (CANTARELLA, 2007). In contrast, insufficient quantities can limit yield potential even when other production factors are optimized (SANTOS et al., 2003).

It has been demonstrated that the bean plant, through symbiosis with nitrogen fixing bacteria that are collectively designated Rhizobium, can achieve elevated productivity levels in field conditions, reaching levels greater than 2,500 $\mathrm{kg} \mathrm{ha}^{-1}$ (HUNGRIA et al., 2000; PELEGRIN et al., 2009). The bean plant is considered to be a promiscuous species; it demonstrates low selectivity and specificity with bacteria of the genus Rhizobium, which is able to establish associations with native Rhizobium and limit biological nitrogen fixation (BNF) efficiency (FERNANDES JÚNIOR; REIS, 2008). Furthermore, other factors can limit the symbiotic potential of the Rhizobium-bean plant interaction, especially water stress (MORAES et al., 2010), high soil temperatures and acidity, in addition to low availability of nutrients such as phosphorous, cobalt, and molybdenum (MARTÍNEZ-ROMERO et al., 1991; MERCANTE et al., 1998; HUNGRIA; CAMPO; MENDES, 2003). In addition to these nutrients, the availability of nitrogen in the soil can also limit the efficiency of biological nitrogen fixation (BNF) because this process only occurs when nitrogen is deficient (CAMPANHARO et al., 2010).

Various species of Rhizobium have been described as being capable of nodulation and, in most cases, fixing $\mathrm{N}_{2}$ in symbiosis with the bean plants $R$. leguminosarum bv. phaseoli (JORDAN, 1984); R. tropici (MARTÍNEZ-ROMERO et al., 1991); R. etli bv. phaseoli (SEGOVIA; YOUNG; MARTÍNEZ-ROMERO, 1993); R. gallicum (bv. gallicum and bv. phaseoli); R. giardinii (bv. giardinii and bv. phaseoli) (AMARGER; MACHERET; LAGUERRE, 1997); and R. leucaenae (RIBEIRO et al., 2011). However, problems related to the genetic instability of many strains of Rhizobium can cause loss of either efficiency or nodulation capacity during stress, which supports the large diversity in the results obtained for inoculation of the bean plant (PEREIRA et al., 1984; PELEGRIN et al., 2009). Recent studies performed analyses on symbiotic and non-symbiotic genes from 15 strains selected from programs located in four distinct geographic regions in Brazil. These analyses demonstrated that all of the strains grouped with either type A or type B $R$. tropici and suggested that the selection of strains of this species could reflect evolutionary 
strategies to maximize nodulation and BNF in the bean plant (PINTO; HUNGRIA; MERCANTE, 2007). Recently, type A strains of $R$. tropici were reclassified as a new species, $R$. leucaenae (RIBEIRO et al., 2011).

Genetic improvement programs in Brazil that seek desirable aspects or characteristics of the bean plant have given priority to the response of new genotypes to mineral nitrogen fertilization in detriment to BNF. Various studies that evaluated the adaptability and stability of new lineages and cultivars of bean plants employed mineral nitrogen fertilization as an experimental plot management technique (BERTOLDO et al., 2009; ROCHA et al., 2010). If the goal is the selection of more efficient genotypes for BNF, nitrogen fertilization must be eliminated in field studies to allow for the selection of adapted and efficient genotypes for the different productive regions. Since its establishment in Brazil, the success obtained in the culture of soy with regards to BNF is due to the incessant search for efficient strains of Rhizobium and responsive cultivars (FERNANDES JÚNIOR; REIS, 2008).

The current challenge faced by improvers and phytotechnicians in bean plant cultivation is the selection of cultivars that are more efficient at biological $\mathrm{N}_{2}$ fixation to minimize or eliminate mineral nitrogen fertilization. We aim to evaluate the efficiency of nodulation and the productive capacity of different bean plant lineages inoculated with $R$. tropici in relation to mineral nitrogen fertilization in the study phase of Value for Cultivation and Use (VCU) tests.

\section{Materials and Methods}

The experiments were conducted using the 2008 (experiment 1) and 2009 crops (experiment 2) in the municipality of Dourados (State of Mato Grosso do Sul, Brazil), which is located at $22^{\circ} 16^{\prime} \mathrm{S}, 54^{\circ} 49^{\prime} \mathrm{W}$, and at an altitude of $408 \mathrm{~m}$. Experiment 1 was planted in the experimental area of the Embrapa Western Region Agriculture (Embrapa Agropecuária Oeste), and experiment 2 was planted in the experimental area of the University for the Development of the State and Region of the Pantanal (UNIDERP-Universidade para o Desenvolvimento do Estado e da Região do Pantanal). The soil in the two experimental areas is a dystrophic red latosol with a clay-like texture (AMARAL et al., 2000; PELEGRIN et al., 2009). The results of the soil chemical analysis for each area are displayed in Table 1.

Table 1. Chemical analyses* of the soil in the experimental areas prior to the start of the experiments in 2008 and 2009. Dourados, MS, Brazil.

\begin{tabular}{ccccccccc}
\hline Year & $\mathrm{pH}$ (water) & $\mathrm{O} . \mathrm{M}$. & $\mathrm{P}$ & $\mathrm{Al}^{3+}$ & $\mathrm{Ca}^{2+}$ & $\mathrm{Mg}^{2+}$ & $\mathrm{K}$ & $\mathrm{V}$ \\
\hline & & $\mathrm{g} \mathrm{kg}^{-1}$ & $\mathrm{mg} \mathrm{dm}^{-3}$ & $-------\mathrm{cmol}_{\mathrm{c}} \mathrm{dm}^{-3}$------------ & $\%$ \\
2008 & 5.9 & 32.7 & 12.3 & 0.0 & 7.1 & 2.7 & 0.82 & 69 \\
2009 & 6.0 & 21.7 & 3.7 & 0.0 & 3.7 & 1.3 & 0.38 & 58 \\
\hline
\end{tabular}

* Analyses performed by the Soil Laboratory of the Embrapa Western Region Agriculture. Extractors: OM = Walkley and Black, P and $\mathrm{K}=$ Mehlich-1, $\mathrm{Al}, \mathrm{Ca}$, and $\mathrm{Mg}=\mathrm{KCl} 1 \mathrm{molL}^{-1} \cdot \mathrm{V}(\%)=(\mathrm{K}+\mathrm{Ca}+\mathrm{Mg}) /(\mathrm{K}+\mathrm{Ca}+\mathrm{Mg}+(\mathrm{H}+\mathrm{Al})) \times 100$

Source: Elaboration of the authors.

Plant fertilization was performed using $300 \mathrm{~kg} \mathrm{ha}^{-1}$ of formula 00-20-20 applied in the planting furrow. Nitrogen fertilization (mineral $\mathrm{N}$ ) for the treatments that were not inoculated consisted of a dose of $80 \mathrm{~kg}$ ha ${ }^{-1}$ of $\mathrm{N}$ (i.e., $40 \mathrm{~kg} \mathrm{ha}^{-1}$ on the plant and the rest on the covering) 30 days after germination using urea as the $\mathrm{N}$ source. 
A direct planting system was employed in experiment 1, while the conventional soil preparation system using a plow with two disks was used in experiment 2. In the two experiments, the experimental plots were sown manually soon after harvesting corn in one area (experiment 1) and after a fallow period in the other area (experiment 2). In the fallow area, there was a predominance of the infesting plant Brachiaria brizantha. The first and second experiments were sown in September 2008 and October 2009, respectively. For each sowing, 15 seeds were distributed per meter. The furrows were spaced $0.50 \mathrm{~m}$ apart. The experiment plot consisted of six lines, four meters in length; two were used for productivity sampling, and one was used for the evaluation of nodulation. The methodology described in Cardoso et al. (2009) was used to evaluate nodulation 30 days after germination. Nodule counting on the roots was performed up to $7 \mathrm{~cm}$ from the crown of the plants located one linear meter from the furrow, which allowed for the evaluation of the aboveground mass.

The experiment consisted of randomized blocks with three repetitions. The treatments tested in both experiments ( 1 and 2 ) resulted in a 2 x 14 factorial arrangement. The factors were the two forms of providing nitrogen (mineral nitrogen fertilization or inoculation with Rhizobium tropici) and different lineages of bean plant from the genetic improvement of the bean plant program determined by VCU tests (Value for Cultivation and Use) of Embrapa Rice and Beans (Embrapa Arroz e Feijão). To increase the number of lineages studied, materials from the 2008 and 2009 VCU tests were used, which totaled 26 new lineages plus the control (averages of varieties of BRS Cometa, BRS Estilo, IPR Juriti, and Pérola). Thus, 14 genotypes were evaluated in each experiment (i.e., 13 new lineages and the control). The evaluated lineages in each experiment were as follows:

Experiment 1/ 2008: CNFC 10703; CNFC 10713; CNFC 10716; CNFC 10721; CNFC 10729; CNFC 10733; CNFC 10742; CNFC 10753; CNFC
10757; CNFC 10758; CNFC 10762; CNFC 10763; and CNFC 10813.

Experiment 2/ 2009: CNFC 10429; CNFC 11944; CNFC 11945; CNFC 11946; CNFC 11948; CNFC 11951; CNFC 11952; CNFC 11953; CNFC 11954; CNFC 11956; CNFC 11959; CNFC 11962; and CNFC 11966.

The seeds were inoculated using the $R$. tropici strains CIAT 899 (SEMIA 4077) + PRF 81 (SEMIA 4080), which is commercially recommended for the bean plant in Brazil. The inoculum was prepared by the FEPAGRO (Fundação Estadual de Pesquisa Agropecuária) [State Foundation for Agricultural Research] using a density of $10^{9}$ cells $\mathrm{g}^{-1}$ of turf, and $500 \mathrm{~g}$ of turf was applied per $50 \mathrm{~kg}$ of seed. Furthermore, $300 \mathrm{~mL}$ of a $10 \%$ (w:v) sugar solution was used to increase the adherence of the turf to the seeds (PELEGRIN et al., 2009).

The plants were harvested when all of the lineages reached physiological maturity. At that time, the following measurements were performed: total $\mathrm{N}$ concentration both aboveground and in the beans (MALAVOLTA; VITTI; OLIVEIRA, 1997), number of pods per plant, number of beans per pod, and productivity (corrected to $13 \%$ humidity). The results were subjected to analysis of variance with splits of the interactions, according to Barbin (2003). When necessary, the averages were compared using the F and Scott-Knott tests to a probability of 5\%.

\section{Results and Discussion}

After evaluating the effect of the inoculation of $R$. tropici (CIAT $899=$ SEMIA $4077+$ PRF 81 $=$ SEMIA 4080) and the application of mineral $\mathrm{N}$ (urea) in experiment 1 (2008), we determined that the lineages CNFC 10813 and CNFC 10716 had a greater number of nodules when inoculated with Rhizobium than when supplied with $40 \mathrm{~kg} \mathrm{ha}^{-1}$ of $\mathrm{N}$ (plant fertilization) (Table 2). In contrast, the CNFC 10758 lineage had more nodules when it received mineral nitrogen fertilization, indicating nodulation 
stimulus via the application of $40 \mathrm{~kg} \mathrm{ha}^{-1}$ at sowing. In the other bean plant genotypes (lineages and cultivars), fertilization using $80 \mathrm{~kg} \mathrm{ha}^{-1}$ of $\mathrm{N}$ and the inoculation of Rhizobium promoted similar nodulation results (Table 2). When inoculated, the CNFC 10716, CNFC 10813, and CNFC 10733 lineages had more dry nodes than the other genotypes that were also inoculated. Differences in the number of dry nodules were not detected among the bean plant genotypes fertilized with mineral nitrogen (Table 2). N. Pelegrin et al. (2009) observed a trend in decreasing nodulation (number and dry matter of nodules) in the Carioca bean plant group (Pérola cultivar) that correlated with an increase in the quantity of $\mathrm{N}$ applied. With regards to the dry mass of the nodules, the CNFC 10753 lineage had a greater number of nodules when inoculated, and the other lineages did not demonstrate a difference in the dry mass of the nodules.

In experiment 2, the CNFC 10429, CNFC 11946, and CNFC 11956 lineages had more nodules than the other evaluated bean plant genotypes when fertilized with mineral $\mathrm{N}$; however, the dry mass of the nodules was similar between all of the genotypes (Table 3). Among the inoculated genotypes, the CNFC 10429, CNFC 11945, CNFC 11951, CNFC 11952, CNFC 11954, CNFC 11959, and CNFC 11962 lineages stood out from the others. The CNFC 10429, CNFC 11952, CNFC 11954, and CNFC 11962 lineages were superior to the other genotypes in the production of dry matter of the nodules of the inoculated bean plants. In the genotypes fertilized with mineral $\mathrm{N}$, differences in the nodular mass were not detected between the plants (Table 3). It should be noted that various genotypes of inoculated bean plants displayed increased nodulation (number and dry matter of nodules) compared to when they were supplied with mineral N, especially the CNFC 11951, CNFC 11952, CNFC 11954, and CNFC 11962 lineages (Table 3). Other studies have also demonstrated a reduction in nodulation after the application of mineral N. Indeed, Mercante, Otsubo, and Lamas (2006) observed significant reductions in the nodulation of bean plant cultivars belonging to the three distinct commercial groups (Carioca (BRS Pontal and BRS Requinte), Rosinha (BRS Vereda), and Roxinho (BRS Timbó)) when supplied with different doses of mineral $\mathrm{N}$ versus plants inoculated with $R$. tropici (CIAT $899+$ PRF 81).

The production of dry matter in the aboveground portion of the bean plant was evaluated. We determined that only the CNFC 10716 and CNFC 10763 lineages (experiment 1), and the CNFC 11945, CNFC 11954, CNFC 11956, and control plants (experiment 2) demonstrated increased production of dry matter using mineral nitrogen fertilization relative to inoculation with Rhizobium. In the other genotypes, differences in the production of dry matter were not detected in the aboveground portion of the plants independent of the source of N (Tables 2 and 3). Studies performed by Souza, Straliotto and Teixeira (2004) determined that some bean plant genotypes were positively influenced by nitrogen fertilization, while others were unchanged. 


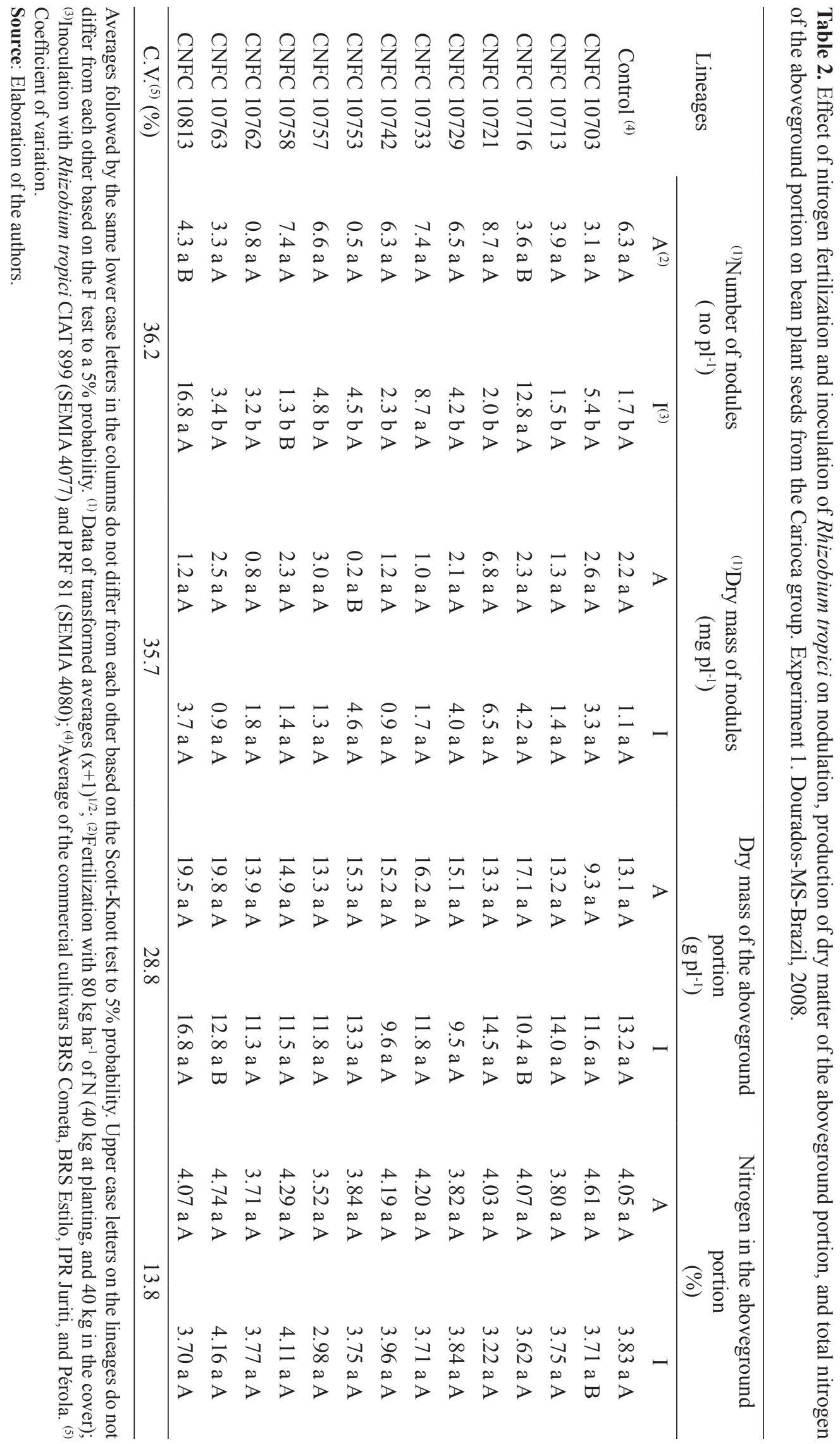




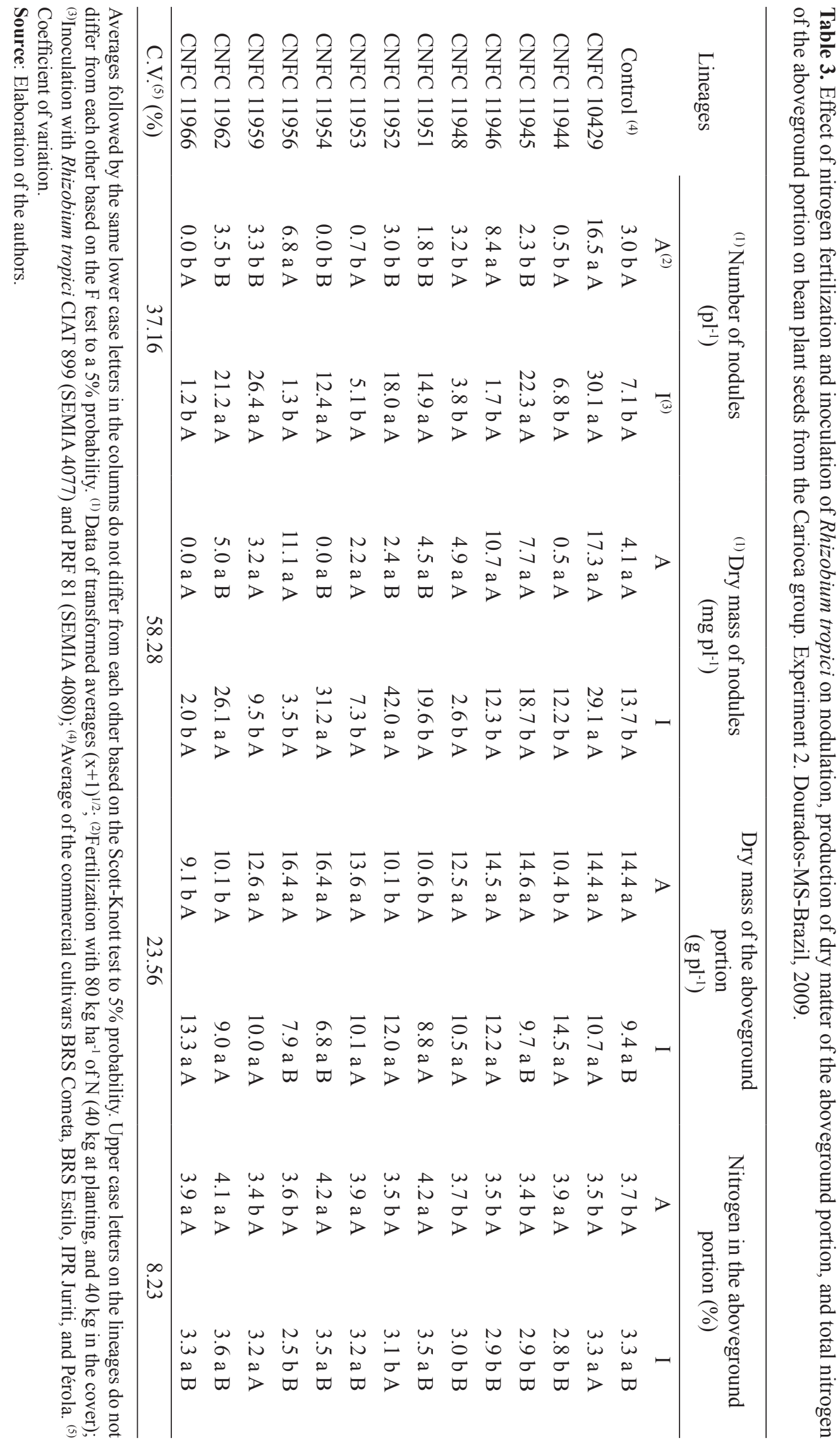


The concentrations of nitrogen in the aboveground portion of the plants and in the beans measured adequate (sufficient) levels for the bean plant according to Fancelli and Dourado Neto (2007) and Pessoa et al. (1996). These results indicated that both methods of providing $\mathrm{N}$ were efficient (Tables $2,3,4$, and 5). In experiment 1 , the concentrations of $\mathrm{N}$ in the aboveground portion of the CNFC 10703 lineage were higher in plants fertilized with mineral $\mathrm{N}$ relative to plants inoculated with Rhizobium. For the other genotypes and the control, the concentrations of $\mathrm{N}$ in the aboveground portion were similar among the plants supplied with $\mathrm{N}$ and the inoculated plants (Table 2). Differences in the concentrations of $\mathrm{N}$ in the aboveground portion of the plants were not observed between the genotypes within each source of $\mathrm{N}$ in the present experiment (Table 2).

In experiment 2, we observed variability between the genotypes and both sources of N. In general, the concentrations of $\mathrm{N}$ in the aboveground portion of the plants fertilized with mineral $\mathrm{N}$ were higher than those in the plants that received inoculation with Rhizobium; exceptions were the CNFC 10429 and CNFC 11852 genotypes, which had similar concentrations of $\mathrm{N}$ from both sources of $\mathrm{N}$ supply (Table 2). The reduction in the concentration of $\mathrm{N}$ in the aboveground portion of the plants and beans were lower in experiment 2, which may have occurred as a function of the management system adopted for cultivation. Reduction in stress due to temperature and humidity in the soil from the direct planting system favored the survival of the rhizobia in the soil, thereby enhancing biological $\mathrm{N}_{2}$ fixation (HUNGRIA; CAMPO; MENDES, 2007) in addition to the increase in the concentrations of organic material (O.M.) in the soil, which provided greater nitrogen availability in the soil because approximately $95 \%$ of nitrogen is associated with
O.M. (SILVA; MENDONÇA, 2007).

In experiment 1, the CNFC 10721, CNFC 10729 , and CNFC 10742 lineages had more pods per plant when fertilized with mineral nitrogen than when inoculated with Rhizobium. In the other genotypes, the number of pods per plant was similar (Table 4). In experiment 2 , differences were not observed between the genotypes that received nitrogen fertilization and those that were inoculated (Table 5). Independent of the experiment, there were no differences in the number of pods per plant within each treatment (fertilization or inoculation) (Tables 4 and 5).

The genotypes did not show significant differences in the number of beans per pod when inoculated with $R$. tropici or when fertilized, with the exception of the CNFC 10763 lineage, which had more beans per pod in the mineral nitrogen fertilization in experiment 1 (Table 4), and the CNFC 11966 lineage when inoculated in experiment 2 (Table 5). When the inoculation with $R$. tropici was evaluated, the genotypes behaved differently. The CNFC 10733, CNFC 10713, CNFC 10757, and CNFC 10703 lineages predominated in experiment 1 (Table 4), and the CNFC 10429, CNFC 11944, CNFC 11952, CNFC 11956, CNFC 11945, CNFC 11953, and CNFC 11966 lineages predominated in experiment 2 (Table 5). The values confirmed in this study were similar to those observed by Lemos et al. (2004), who also evaluated the genotypes of the commercial Carioca bean plant group.

No differences were observed in the mass of 100 beans when comparing the inoculation with $R$. tropici and mineral $\mathrm{N}$ fertilization in the bean plants lineages (Tables 4 and 5). These results are similar to those observed by Vieira et al. (2000) and Lemos et al. (2003). In experiment 2, differences in the genotypes that received nitrogen fertilization were observed (Table 5). 


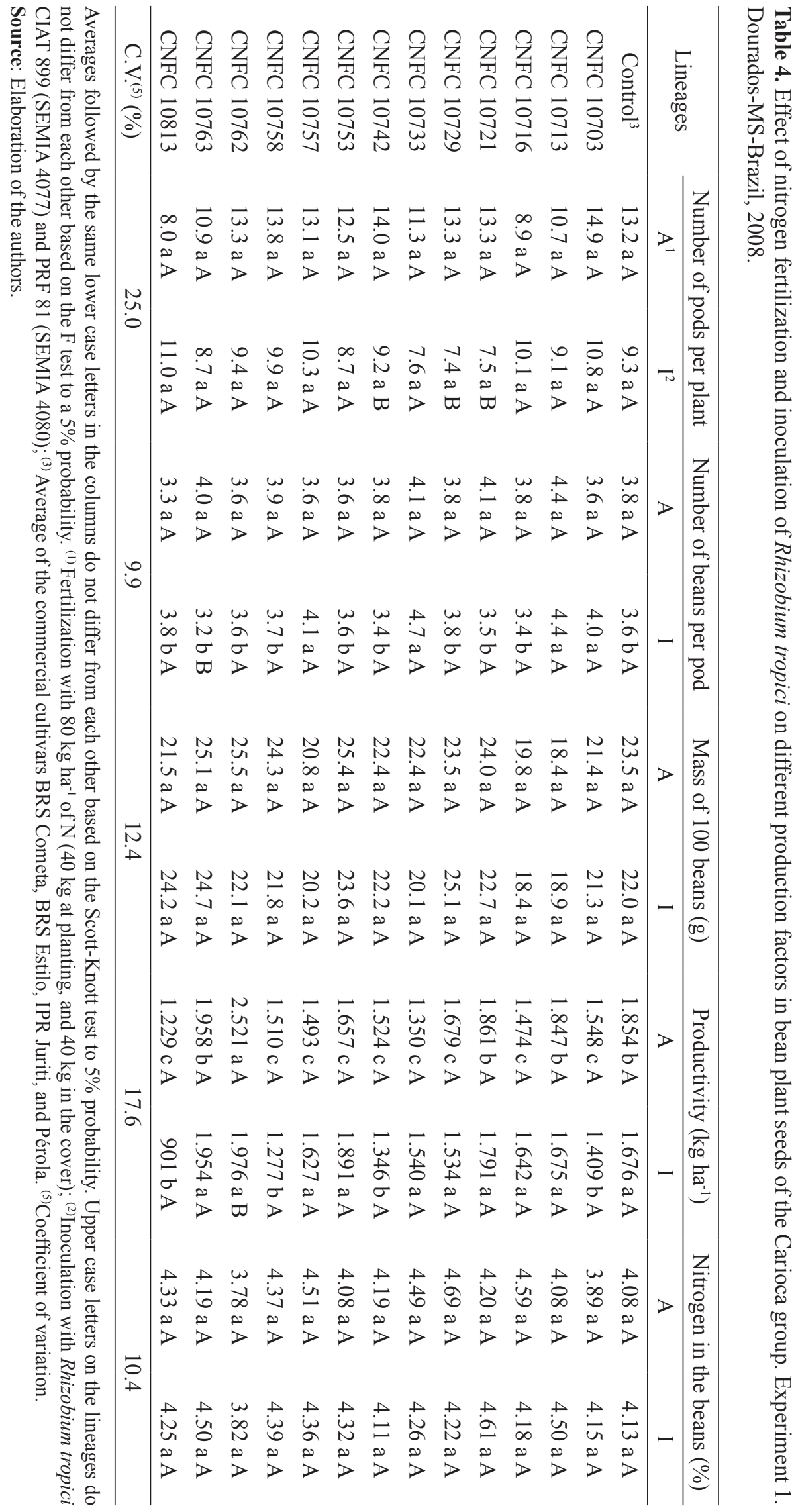




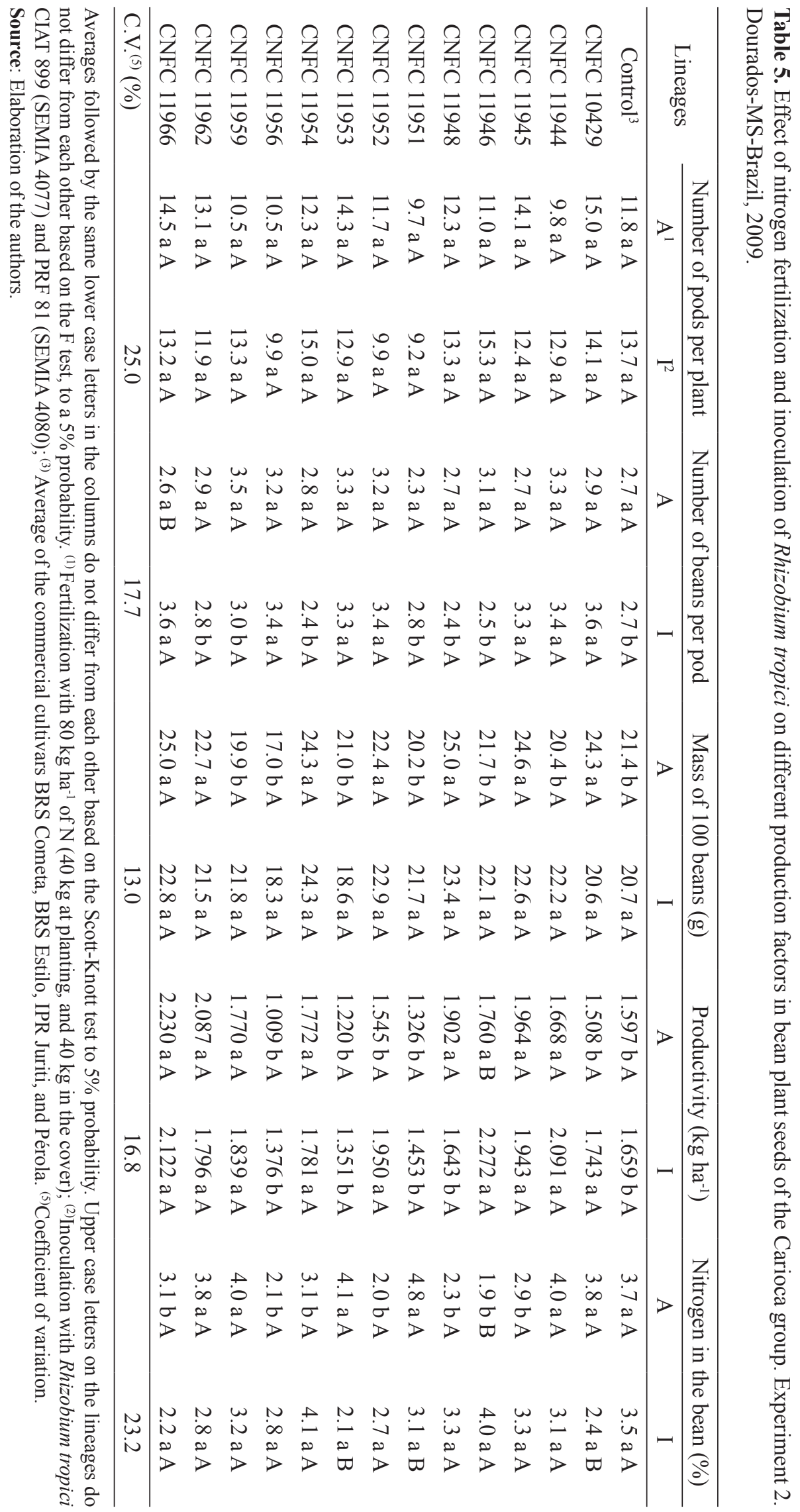


For the majority of the genotypes, differences were not observed between inoculation with Rhizobium and the application of $80 \mathrm{~kg} \mathrm{ha}^{-1}$ of $\mathrm{N}$ with respect to productivity (bean yield). One exception was the CNFC 10762 lineage, which demonstrated greater productivity when fertilized with mineral $\mathrm{N}$ (Table 4). Additionally, the CNFC-10721 lineage displayed greater productivity when inoculated with Rhizobium (Table 5). These results indicate that the use of rhizobia inocula are very important for the cultivation of bean plants, can reduce production costs significantly, and can increase the net revenue of the producers, as verified by Pelegrin et al. (2009).

The interaction between bean plant genotype and $\mathrm{N}_{2}$ fixing bacteria has also been evaluated using the gene pool. Two known origins are Mesoamerican and Andean (SINGH; GEPTS; DEBOUCK, 1991). Franco et al. (2002) determined the nodulation capacity and the specificity of the common bean plant from Andean and Mesoamerican gene pools subjected to inoculation with different strains of rhizobia and 14 cultivars of bean plant. They verified that only four Andean cultivars (WAF 15, WAF 7 , Mineiro Precoce, WAF 6, and Antioquia 8) showed specificity in nodulation. These authors verified significant differences in the dry mass of nodules in the inoculation treatments in Andean cultivars WAF 15, WAF 7, WAF 6, and Diacol Andino, and in the Mesoamerican cultivar Ouro Negro.

It must be emphasized that studies on the development of cultivars that are more efficient in BNF have been little explored; although, the variability of the response of different bean plant cultivars to inoculation with rhizobia has been demonstrated in various studies (DÖBEREINER; RUSCHEL, 1961; HARDARSON et al., 1993; PERES et al., 1994). Thus, the results obtained in the present study may contribute to future studies that seek to identify varieties with improved BNF performance instead of mineral nitrogen fertilization.

\section{Conclusions}

1. The different behaviors in nodulation and phytotechnical parameters of some lineages demonstrate that the source of $\mathrm{N}$ (inoculation with Rhizobium or nitrogen fertilization) in studies on genetic improvement for the selection of bean plant cultivars can directly influence their productive potential.

2. Depending on the bean lineage, bean plant yields are similar between plants inoculated with $R$. tropici and those fertilized with $80 \mathrm{~kg} \mathrm{ha}^{-1}$ of $\mathrm{N}$.

\section{Acknowledgments}

The authors acknowledge the Embrapa Arroz e Feijão (Embrapa Rice and Beans) for providing the bean plant lineages, the Fundect-MS for the grant to the first author, and the National Research Council) for the Productivity in Research grant provided to the third author.

\section{References}

AMARAL, J. A. M. do; MOTCHI, E. P.; OLIVEIRA, H. de; CARVALHO FILHO, A. de; NAIME, U. J.; SANTOS, R. D. dos. Levantamento semidetalhado dos solos do Campo Experimental de Dourados, da Embrapa Agropecuária Oeste, Município de Dourados, MS. Dourados: Embrapa Agropecuária Oeste; Rio de Janeiro: Embrapa Solos, 2000. 68 p. (Embrapa Agropecuária Oeste. Documentos, 22. Embrapa Solos. Documentos, 15).

AMARGER, N.; MACHERET, V.; LAGUERRE, G. Rhizobium gallicum sp. nov. and Rhizobium giardinii sp. nov. from Phaseolus vulgaris nodules. International Journal of Systematic and Evolutionary Bacteriology, Reading, v. 47, n. 4, p. 996-1006, 1997.

BARBIN, D. Planejamento e análise de experimentos agronômicos. Arapongas: Midas, 2003. 208 p.

BERTOLDO, J. G.; COIMBRA, J. L. M.; TAVARES, H. E.; HEMP, S.; VOGT, G. A.; ROCHA, F. da; STAHELIN, D. Adaptabilidade e estabilidade fenotípica para o caráter tempo de cocção do feijão preto. Revista Ceres, Viçosa, MG, v. 56, n. 3, p. 315-321, 2009.

BINOTTI, F. F. da S.; ARF, O.; CARDOSO, E. D.; SÁ, 
M. E. de; BUZETTI, S.; NASCIMENTO, V. do. Fontes e doses de nitrogênio em cobertura no feijoeiro de inverno irrigado no sistema plantio direto. Bioscience Journal, Uberlândia, MG, v. 26, n. 5, p. 770-778, 2010.

CAMPANHARO, M.; LIRA JUNIOR, M. A.; NASCIMENTO, C. W. A.; STAMFORD, N. P.; FREIRE, F. J.; COSTA, J. V. T. da. Acidez do solo na fixação biológica de nitrogênio em feijoeiro comum. Revista Brasileira de Ciências Agrárias, Recife, v. 5, n. 3, p. 285290. 2010.

CANTARELLA, H. Nitrogênio. In: NOVAIS, R. F.; ALVAREZ V., V. H.; BARROS, N. F. de; FONTES, R. L. F.; CANTARUTTI, R. B.; NEVES, J. C. L. (Ed.). Fertilidade de solos. Viçosa, MG: Sociedade Brasileira de Ciência do Solo, 2007. p. 376-470.

CARDOSO, J. D.; GOMES, D. F.; GOES, K. C. G. P.; FONSECA JUNIOR, N. da S.; DORIGO, O. F.; ANDRADE, D. S. Relationship between total nodulation and nodulation at the root crown of peanut, soybean and common bean plants. Soil Biology \& Biochemistry, Oxford, v. 41, n. 8, p. 1760-1763, 2009.

COMISSÃO TÉCNICA SUL-BRASILEIRA DE FEIJÃO. Informações técnicas para o cultivo do feijão na Região Sul Brasileira 2009. Florianópolis: Epagri, 2010. 164 p.

DÖBEREINER, J.; RUSCHEL, A. P. Fixação simbiótica do nitrogênio atmosférico em feijão (Phaseolus vulgaris L.). I- Influência do solo e da variedade. Rio de Janeiro: Instituto de Ecologia e Experimentação Agrícola, 1961. 16 p. (IEEA. Comunicado técnico, 10).

FANCELLI, A. L.; DOURADO NETO, D. Produção de feijão. Piracicaba. 2007. 386 p.

FERNANDES JÚNIOR, P. I.; REIS, V. M. Algumas limitações à fixação biológica de nitrogênio em leguminosas. Seropédica: Embrapa Agrobiologia, 2008. 33 p. (Embrapa Agrobiologia, Documentos, 252).

FRANCO, M. C.; CASSINI, S. T. A.; OLIVEIRA, V. R.; VIEIRA, C.; TSAI, S. M. Nodulação em cultivares de feijão dos conjuntos gênicos andino e meso-americano. Pesquisa Agropecuária Brasileira, Brasília, v. 37, p. 1145-1150, 2002.

HARDARSON, G.; BLISS, F. A.; GIGALES-RIVERO, M. R.; HENSON, R. A.; KIPE-NOLT, J. A.; LONGERI, L.; MANRIQUE, A.; PEÑA-CABRIALES, J. J.; PEREIRA, P. A. A.; SANABRIA, C. A.; TSAI, S. M. Genotypic variation in biological nitrogen fixation by common bean. Plant and Soil, Dordrecht, v. 159, p. 5970, 1993.

HUNGRIA, M.; ANDRADE, D. S.; CHUEIRE, L. M. O.; PROBANZA, A.; GUTIERREZ-MAÑERO, F. J.;
MEGIAS, M. Isolation and characterization of new efficient and competitive bean (Phaseolus vulgaris L.) rhizobia from Brazil. Soil Biology \& Biochemistry, Oxford, v. 32, n. 11-12, p. 1515-1528, 2000.

HUNGRIA, M.; CAMPO, R. J.; MENDES, I. C. A importância do processo de fixação biológica do nitrogênio para a cultura da soja: componente essencial para a competitividade do produto brasileiro. Londrina: Embrapa Soja, 2007. 80 p. (Embrapa Soja. Documentos, 283).

Benefits of inoculation of the common bean (Phaseolus vulgaris) crop with efficient and competitive Rhizobium tropici strains. Biology and Fertility of Soils, Berlim, v. 39, n. 2, p. 88-93, 2003.

JORDAN, D. C. Family III rhizobiaceae. Conn. 1938. In: KRIEG, N. R.; HOLT, J. G. (Ed.). Bergey's manual of systematic bacteriology. Baltimore: Williams \& Wilkins, 1984. p. 234-256.

LEMOS, L. B.; FORNASIERI FILHO, D.; CAMARGO, M. B.; SILVA, T. R. B. da; SORATTO, R. P. Inoculação de rizóbio e adubação nitrogenada em genótipos de feijoeiro. Agronomia, Seropédica, v. 37, n. 1, p. 26-31, 2003.

LEMOS, L. B.; OLIVEIRA, R. S. de; PALOMINO, E. C.; SILVA, T. R. B. da. Características agronômicas e tecnológicas de genótipos de feijão do grupo comercial Carioca. Pesquisa Agropecuária Brasileira, Brasília, 39, n. 4, p. 319-326, 2004.

MALAVOLTA, E.; VITTI, G. C.; OLIVEIRA, S. A. de. Avaliação do estado nutricional das plantas: princípios e aplicações. 2. ed. rev. atual. Piracicaba: POTAFOS, 1997. $319 \mathrm{p}$.

MARTÍNEZ-ROMERO, E.; SEGOVIA, E.; MERCANTE, F. M.; FRANCO, A. A.; GRAHAN, P. H.; PARDO, M. A. Rhizobium tropici, a novel species nodulation Phaseolus vulgaris L. beans and Leucaena $s p$. trees. International Journal Systematic Bacteriology, Washington, DC, v. 41, n. 3, p. 417-426, 1991.

MERCANTE, F. M.; CUNHA, C. O.; STRALIOTTO, R.; RIBEIRO-JUINIOR, W. Q.; VANDERLEYDEN, J.; FRANCO, A. A. Leucaena leucocephala as a traphost for Rhizobium tropici strain from the Brazilian cerrado region. Revista de Microbiologia, São Paulo, v. 29, n. 1, p. 49-58, 1998.

MERCANTE, F. M.; OTSUBO, A. A.; LAMAS, F. M. Inoculação de Rhizobium tropici e aplicação de adubo nitrogenado na cultura do feijoeiro. In: REUNIÃO BRASILEIRA DE FERTILIDADE DE SOLO E NUTRIÇÃO DE PLANTAS, 27.; REUNIÃO BRASILEIRA SOBRE MICORRIZAS, 11.; SIMPÓSIO 
BRASILEIRO DE MICROBIOLOGIA DO SOLO, 9.; REUNIÃO BRASILEIRA DE BIOLOGIA DO SOLO, 6., 2006, Dourados. Anais... Dourados: Embrapa Agropecuária Oeste, 2006. 1 CD-ROM. (Embrapa Agropecuária Oeste. Documentos, 82).

MORAES, W. B.; MARTINS FILHO, S.; GARCIA, G. de O.; CAETANO, S. de P.; MORAES, W. B.; COSMI, F. C. Avaliação da fixação biológica do nitrogênio em genótipos de feijoeiros tolerantes a seca. IDESIA, Arica, v. 28, n. 1, p. 61-68, 2010.

PELEGRIN, R. de; MERCANTE, F. M.; OTSUBO, I. M. N.; OTSUBO, A. A. Resposta da cultura do feijoeiro à adubação nitrogenada e à inoculação com rizóbio. Revista Brasileira de Ciência do Solo, Viçosa, MG, v. 33, n. 1, p. 219-226, 2009.

PEREIRA, P. A. A.; ARAÚJO, R. S.; ROCHA, R. E. M.; STEINMETZ, S. Capacidade de genótipos de feijoeiro de fixar $\mathrm{N}_{2}$ atmosférico. Pesquisa Agropecuária Brasileira, Brasília, DF, v. 19, n. 7, p. 811-815, 1984.

PERES, J. R. R.; SUHET, A. R.; MENDES, I. C.;VARGAS, M. A. T. Efeito da inoculação com rizóbio e da adubação nitrogenada em sete cultivares de feijão em um solo de cerrados. Revista Brasileira de Ciência do Solo, Viçosa, MG, v. 18, n. 3, p. 415-420, 1994.

PESSOA, A. C. S.; LELlinG, C. R. S.; POZZEBON, E. J.; KONIG, O. O. Concentração e acumulação de nitrogênio, fósforo e potássio pelo feijoeiro cultivado sob níveis de irrigação. Ciência Rural, Santa Maria, v. 26, n. 1, p. 69-74. 1996.

PINTO, F. G. S.; HUNGRIA, M.; MERCANTE, F. M. Polyphasic characterization of Brazilian Rhizobium tropici strains effective in fixing $\mathrm{N}_{2}$ with common bean (Phaseolus vulgaris L.) Soil Biology \& Biochemistry, Oxford, v. 39, n. 8, p. 1851-1864, 2007.

RIBEIRO, R. A.; ROGEL, M. A.; LÓPEZ-LÓPEZ, A.; ORMEÑO-ORRILLO, E.; BARCELLOS, F. G.; MATÍNEZ, J.; THOMPSON, F. L.; MARTÍNEZROMERO, E.; HUNGRIA, M. Reclassification or
Rhizobium tropici type A strains as Rhizobium leucaenae sp. Nov. International Journal of Systematic and Evolutionary Microbiology, Reading, v. 62, n. 5, p. 11791184, 2011.

ROCHA, V. P. C.; MODA-CIRINO, V.; DESTRO, D.; FONSECA JÚNIOR, $\mathrm{N}$ da S.; PRETE, C. E. C. Adaptabilidade e estabilidade da característica produtividade de grãos dos grupos comerciais Carioca e preto de feijão. Semina: Ciências Agrárias, Londrina, v. 31, n. 1, p. 39-54, 2010.

SANTOS, A. B.; FAGERIA, N. K.; SILVA, O. F.; MELO, M. L. B. Resposta do feijoeiro ao manejo de nitrogênio em várzeas tropicais. Pesquisa Agropecuária Brasileira, Brasília, DF, v. 38, n. 11, p. 1265-1271, 2003.

SEGOVIA, L.; YOUNG, J. P. W.; MARTÍNEZROMERO, E. Reclassification of American Rhizobium leguminosarum biovar phaseoli type I strains as Rhizobium etli sp. Nov. International Journal of Systematic Bacteriology, Washington, DC, v. 43, n. 2, p. 374-377, 1993.

SILVA, I. R.; MENDONÇA, E. de S. Matéria orgânica do solo. In: NOVAIS, R. F.; ALVAREZ V., V. H.; BARROS, N. F. de; FONTES, R. L. F.; CANTARUTTI, R. B.; NEVES, J. C. L. (Ed.). Fertilidade de solos. Viçosa: Sociedade Brasileira de Ciência do Solo, 2007. p. 275374.

SINGH, S. P.; GEPTS, P.; DEBOUCK, D. G. Races of common bean (Phaseolus vulgaris, Fabaceae). Economic Botany, New York, v. 45, n. 3, p. 379-396, 1991.

SOUZA, R. de F.; STRALIOTTO, R.; TEIXEIRA, M. G. Especificidade entre linhagens de feijoeiro (Phaseolus vulgaris L.) tipo Jalo e estirpes de rizóbio. Revista Universidade Rural: Série Ciências da Vida, Seropédica, v. 24, n. 1, p. 19-24. 2004.

VIEIRA, S. M.; RONZELLI JÚNIOR, P.; DAROS, E.; KOEHLER, H. S.; PREVEDELLO, B. M. S. Nitrogênio, molibdênio e inoculante para a cultura do feijoeiro. Scientia Agrícola, Piracicaba, v. 1, n. 1-2, p. 63-66, 2000. 
